Jurnal

Kardiologi Indonesia

J Kardiol Indones. 2016;37:38-46

ISSN $0126 / 3773$

\title{
Neurohormonal Activation and Left Atrium Remodeling in Mitral Stenosis
}

\author{
Vidya Gilang Rejeki, Bambang Budi Siswanto, Nani Hersunarti
}

Departemen Kardiologi dan Kedokteran Vaskular, Universitas Gadjah Mada / RSUP Dr. Sardjito, Yogyakarta, Indonesia
Mitral stenosis is closely related with the hemodynamic consequences of obstructed mitral leaflet. Definitive therapy in mitral stenosis is mechanical intervention. Late presentation of mitral stenosis patients to medical facilities due to limited health facilities and Indonesian's demographic, often make patients' condition deteriorates, in which intervention need to be delayed or even no longer suitable. Stretched left atrium and reduced cardiac output stimulate several neurohormonal activation; renin-angiotensin-aldosterone and symphatetic nervous system. Left atrial remodeling further worsen hemodynamic ststus. Renin-angiotensin-aldosterone and sympathetic blockage could improve mitral stenosis patients' condition with close observation to hypotension status.

(J Kardiol Indones. 2016;37:38-46)

Keywords: Left Atrial Neurohormonal activation, Left Atrial Remodeling, Mitral Stenosis 


\title{
Aktivasi Neurohormonal dan Remodeling Atrium Kiri pada Stenosis Mitral
}

\author{
Vidya Gilang Rejeki, Bambang Budi Siswanto, Nani Hersunarti
}

\begin{abstract}
Gejala dari stenosis mitral berkaitan erat dengan konsekuensi hemodinamik yang diakibatkan oleh obstruksi dari katup mitral. Terapi definitive pasien dengan stenosis mitral adalah intervensi mekanik baik dengan komisurotomi mitral perkutan atau pun intervensi bedah. Keterlambatan presentasi pasien pada akses medis yang didukung oleh keterbatasan fasilitas kesehatan dan letak demografis Indonesia, terkadang membuat keadaan pasien hadir dengan presentasi yang lebih berat. Sehingga tidak jarang suatu tindakan, baik intervensi non bedah atau pun intervensi bedah harus ditunda dengan memberikan optimalisasi medika mentosa terlebih dahulu. Peregangan atrium kiri dan penurunan curah jantung mengaktifkan serangkaian aktivasi neurohormonal. Remodeling atrium kiri diperantai oleh aktivasi sistem renin-angiotensin-aldosteron (RAAS) dan simpatis yang memperburuk gejala dari pasien dengan stenosis mitral. Blokade dari aktivasi RAAS dan simpatis dapat memperbaiki gejala pada pasien dengan stenosis mitral dengan melakukan observasi pada status hipotensi.
\end{abstract}

(J Kardiol Indones. 2016;37:38-46)

Kata Kunci: Aktivitas neurohomonal atrium kiri, remodeling atrium kiri, stenosis mitral

Stenosis mitral berkaitan dengan morbiditas dan mortalitas, dengan penyebab tersering adalah penyakit jantung rematik $95-99.3 \% .{ }^{1}$ Prevalensi stenosis mitraldi negara berkembang masih cukup tinggi.Di Pusat Jantung Nasional Harapan Kita (PJNHK) didapatkan 160-250 kasus stenosis mitral rawat inap per tahun, pada tahun 2010-2014. ${ }^{2}$ Terapi definitif pasien dengan stenosis mitral adalah intervensi mekanik baik dengan komisurotomi mitral perkutan atau pun intervensi bedah. ${ }^{3}$ Namun ada beberapa faktor yang menyebabkan penundaan dari tindakan intervensi;

\section{Alamat Korespondensi}

dr. Vidya Gilang Rejeki, E-mail: vidya.rejeki@gmail.com dan vidya. rejeki@yahoo.com antara lain keadaan atau klinis pasien, maupun antrian dari penjadwalan.

Keterlambatan presentasi pasien pada akses medis yang didukung oleh keterbatasan fasilitas kesehatan dan letak demografis Indonesia, juga membuat keadaan pasien hadir dengan presentasi yang lebih berat.Sehingga tidak jarang suatu tindakan, baik intervensi non bedah atau pun intervensi bedah harus ditunda dengan memberikan optimalisasi medikamentosa terlebih dahulu.Pada tahun 20112013, sekitar 310-360 pasien menjalani operasi katup jantung setiap tahunnya di RS Jantung dan Pembuluh Darah Harapan Kita, padahal berdasarkan data epidemiologi, prevalensi penyakit jantung rematik di Indonesia mencapai 0.8 per 1000 penduduk. Hal ini sering berkaitan dengan peningkatan morbiditas, rehospitalisasi dan juga mortalitas. ${ }^{4-6}$ 
Konsekuensi hemodinamik dari stenosis mitral adalah peningkatan tekanan atrium kiri yang akan menyebabkan peningkatan tekanan pembuluh darah paru dan juga peningkatan tekanan atrium dan ventrikel kanan. Penurunan pengisian ventrikel kiri dan dilatasi progresif rongga jantung kanan serta penurunan fungsi jantung kanan berakibat pada penurunan curah jantung secara global. ${ }^{7} \mathrm{Hal}$ ini yang mendasari suatu keadaan low output atau hipotensi yang sering terjadi pada pasien stenosis mitral.

Peregangan dari atrium kiri dan penurunan curah jantung akan mengaktifkan sistem neurohormonal; aktivasi sistem renin-angiotensin-aldosteron (RAAS) dan sistem simpatis. Aktivasi sistem neurohormonal ini menyebabkan fibrosis, hipertrofi jaringan miokard dan remodeling. ${ }^{8,9}$ Penyekat EKA telah terbukti meningkatkan survival pada pasien gagal jantung dengan efek anti fibrosis, antiproliferatif dan modulasi neurohumoral. ${ }^{10}$ Beberapa clinical trial juga melaporkan efek menguntungkan dari penyekat EKA terhadap reduksi peregangan atrium kiri, pencegahan fibrosis atrium dan kejadian atrial fibrilasi pada pasien gagal jantung. ${ }^{11,12}$ Chockalingam et al. melaporkan keamanan pemberian enalapril dan peningkatan kapasitas fungsional pada pasien stenosis mitral. ${ }^{13}$ Namun, kekhawatiran pemberian penyekat EKA pada pasien dengan stenosis mitral masih sering dihadapi karena khawatir akan jatuhnya ke keadaan low output atau hipotensi.Tinjauan pustaka ini berkaitan dengan tesis yang berjudul "Efek Penyekat EKA Dosis Kecil terhadap 6MWT dan NT-proBNP pada Stenosis Mitral tanpa Hipotensi”.

\section{Stenosis Mitral}

Stenosis mitral merupakan komplikasi penyakit katup tersering dari penyakit jantung rematik.Pada negara maju, prevalensinya sudah sangat menurun, sedangkan di negara berkembang prevalensinya masih cukup tinggi.Stenosis mitral dengan etiologi penyakit jantung rematik memiliki karakteristik yang khas, ditandai dengan fusi dari komisura daun katup mitral, pemendekan dan fusi dari chordae disertai penebalan daun katup yang diikuti dengan kalsifikasi. Hal ini menyebabkan restriksi pergerakan katup. Karakteristik tersebut berbeda dengan stenosis mitral oleh etiologi lainnya seperti degeneratif ataupun kongenital yang umumnya tidak disertai fusi dari komisura. ${ }^{14}$

\section{Klasifikasi Stenosis Mitral}

Luas area katup mitral normal adalah 4.0-5.0 $\mathrm{cm}^{2}$. Berdasarkan severitasnya, stenosis mitral diklasifikasikan menjadi tiga; ringan, sedang dan berat.Stenosis mitral diklasifikasikan sebagai berat ketika luasarea katup mitral $<1.0 \mathrm{~cm}^{2}$, gradien transmitral $>10 \mathrm{mmHg}$ dan tekanan sistolik arteri pulmonal $>50 \mathrm{mmHg}$. Sedangkan klasifikasi stenosis mitral sedang yaitu luasarea katup mitral $1.0-1.5 \mathrm{~cm}^{2}$, gradien transmitral $5-10 \mathrm{mmHg}$, dan tekanan sistolik arteri pulmonal $30-50 \mathrm{mmHg}$. Ketika luas area katup mitral $>1.5 \mathrm{~cm}^{2}$ biasanya tidak menimbulkan gejala, diklasifikasikan sebagai stenosis mitral ringan (table 1). ${ }^{14}$

Tabel 1. Klasifikasi Severitas Stenosis Mitral ${ }^{14}$

\begin{tabular}{|c|c|c|c|}
\hline & Mild & Moderate & Severe \\
\hline \multicolumn{4}{|l|}{ Specific findings } \\
\hline Valve area $\left(\mathrm{cm}^{2}\right)$ & $>1.5$ & $1.0-1.5$ & $<1.0$ \\
\hline \multicolumn{4}{|l|}{ Supportive findings } \\
\hline Mean gradient $(\mathrm{mmHg})^{a}$ & $<5$ & $5-10$ & $>10$ \\
\hline Pulmonary artery pressure $(\mathrm{mmHg})$ & $<30$ & $30-50$ & $>50$ \\
\hline
\end{tabular}

aAt heart rates between 60 and $80 \mathrm{bpm}$ and in sinus thythm.

\section{Patofisiologi Stenosis Mitral}

Pada keadaan normal, ketika luas area katup mitral 4-5 $\mathrm{cm}^{2}$, perbedaan tekanan atrium dan ventikel kiri pada awal fase diastolik akan memberikan pengisian ventrikel kiri sehingga tekanan pada atrium dan ventrikel kiri samasepanjang fase diastolik (gambar 1.1). ${ }^{15}$ Pada stenosis mitral, bukaan katup mitral yang menyempit membuat terhambatnya pengisian ventrikel kiri sehingga terdapat perbedaan tekanan antara atrium dan ventrikel kiri (gambar 1.1). ${ }^{15}$ Peningkatan tekanan diastolik ventrikel kiri akan menyebabkan peningkatan tekanan atrium kiri yang pada akhirnya membuat suatu dilatasi atrium kiri dan kongesti paru. Pengisian ventrikel kiri akan terganggu bergantung dengan tingkat keparahan stenosis katup mitral. Semakin kecil luas area katup mitral, restriksi aliran dari atrium ke ventrikel kiri akan semakin besar menyebabkan keterbatasan penurunan curah jantung, yang dapat menyerupai keadaan gagal jantung kiri. Sepertiga pasien stenosis mitral memiliki penurunan preload karena terganggunya pengisian ventrikel kiri dan peningkatan afterload sekunder dari refleks vasokontriksi karena curah jantung yang menurun. ${ }^{16}$ Namun, umumnya pada kasus stenosis mitral, kontraktilitas jantung kiri baik. Walau demikian, 
di negara berkembang, inflamasi pada penyakit jantung rematik yang sangat agresif dapat menyebabkan gangguan kontraktilitas ventrikel kiri. ${ }^{15}$

Pada stenosis mitral, terjadi remodeling atrium kiri, peningkatan kekakukan atrium kiri, dan gangguan kontraksi atrium kiri. Derajat remodeling atrium

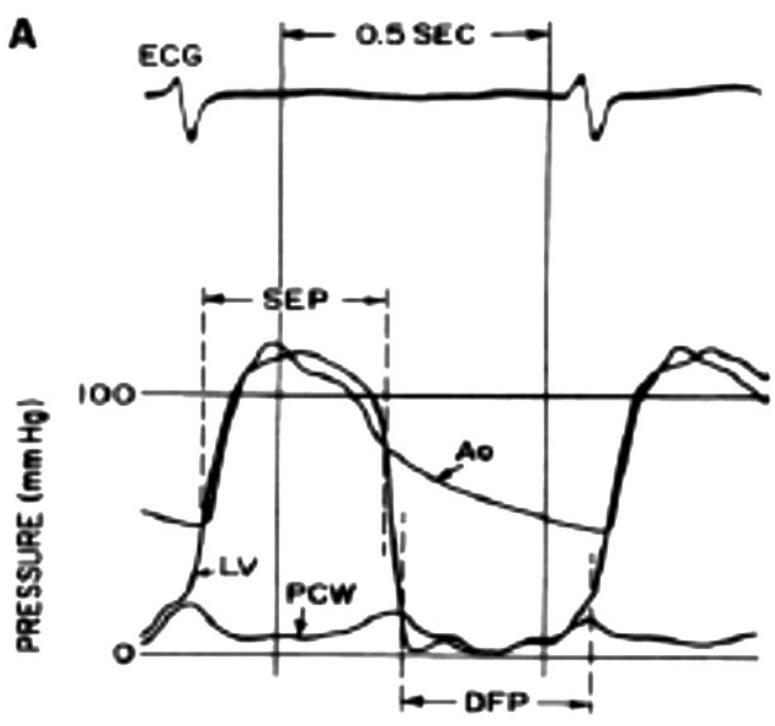

B

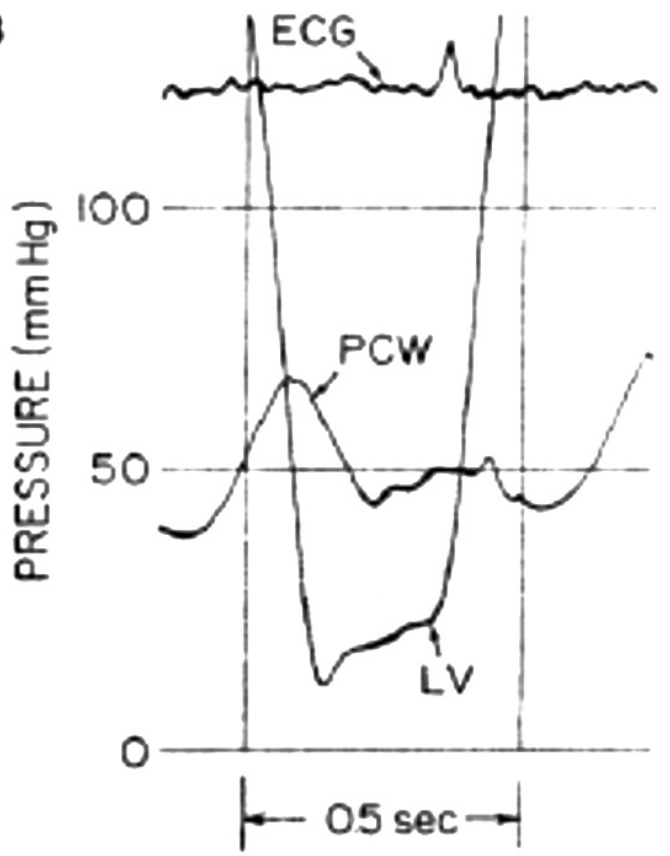

Gambar 1.1 perbandingan tekanan pada ventrikel kiri, aorta, pulmonary capillary wedge pressure pada keadaan normal dan pasien dengan stenosis katup mitral ${ }^{15}$ berasosiasi dengan gangguan kapasitas reservoir, merupakan prediktor yang independen dari luas area katup mitral. ${ }^{17}$

Komplikasi dari stenosis mitral berhubungan dengan konsekuensi hemodinamiknya.Peningkatan tekanan di atrium kiri akibat dari obstruksi katup mitral menyebabkan peningkatan tekanan pembuluh darah kapiler paru. Edema paru dapat terjadi apabila tekanan pembuluh darah kapiler paru melebihi 25 $\mathrm{mmHg}$, menyebabkan transudasi ke interstitial paru dan alveoli. ${ }^{18}$ Peningkatan tekanan pada atrium kiri juga dapat menyebabkan dilatasi atrium kiri dan berkontribusi pada atrial fibrilasi.Atrial fibrilasi juga memperburuk keadaan hemodinamik stenosis mitral dengan hilangnya kontraksi atrium (atrial kick) dan pemendekan fase diastolik yang menyebabkan penurunan pengisian ventrikel kiri.Suatu atrial fibrilasi juga berkaitan erat dengan emboli sistemik, sebagai hasil dari aliran lambat pada atrium yang dilatasi.

\section{ANP dan NT pro-BNP pada Stenosis Mitral}

Obstruksi katup mitral menyebabkan penurunan isi sekuncup dan peningkatan tekanan di atrium kiri yang progesif mengaktifkan serangkaian kaskade neurohormonal. Peregangan atrium kiri merupakan stimulus kuat untuk sekresi atrial natriuretic peptide (ANP), yang diperantai oleh endothelin dan dihambat oleh nitrit oksida. Sekresi ANP juga dipengaruhi oleh stimulus norepinephrine, epinephrine, angiotensin II, dan vasopressin, serta peregangan dari atrium dan ventrikel. ${ }^{19} \mathrm{ANP}$ memiliki berbagai efek fisiologis seperti natriuresis, diuresis, vasodilatasi, dan supresi aktivasi sistem renin-angiotensin-aldosteron (RAAS). Pada pasien stenosis mitral, kadar ANP meningkat seiring dengan derajat keparahan stenosis mitral, dan pulmonary capillary wedge pressue (PCWP). ${ }^{20}$ Peningkatan ANP ini dikatakan merupakan respon adaptif sebagai aksi supresi terhadap RAAS, namun sekresi ANP ini nampaknya tidak cukup untuk supresi RAAS yang teraktivasi. Maeda et al. melaporkan peningkatan tekanan atrium kiri yang progresif pada jangka waktu yang lama menyebabkan kerusakan serta fibrosis miosit atrium yang mengandung granule ANP, menjelaskan kadar ANP yang rendah pada beberapa pasien stenosis mitral dengan atrium kiri yang dilatasi. ${ }^{21}$ 
Brain natriuretic peptide (BNP), memiliki struktur peptida yang sama dengan ANP dan C-type natriuretic peptide (CNP); merupakan neurohormone kardiak yang disekresikan secara dominan oleh ventrikel dan sebagian atrium memliki peran regulator dan modulator pada sistem kardiovaskular dengan aksi diuresis, natriuresis dan vasodilator. $N$-Terminal pro $B$ type natriuretic peptide(NT-proBNP) merupakan prepro BNP yang disekresikan dengan BNP secara bersamaan dan proporsi yang ekuivalen. Namun, NT-proBNP lebih stabil untuk dideteksi di plasma dengan waktu paruh 60-120 menit, dibandingkan dengan BNP yang hanya 20 menit. ${ }^{22}$ Haug et al. meneliti plasma konsentrasi ANP dan BNP pada arteri pulmonal, ventrikel kiri, serta vena femoralis saat diagnostik kateterisasi kardiak, didapatkan plasma konsentrasi BNP pada femoral 10\% lebih rendah dari kadarnya di ventrikel kiri, sedangkan kadar ANP di vena femoralis $30 \%$ lebih rendah. Studi Haug et al. ini selaras dengan Mukoyama et al. yang melaporkan bahwa pada pasien gagal jantung, BNP berada di sirkulasi lebih lama dibandingkan dengan ANP. ${ }^{23}$

Beberapa studi menunjukkan suatu korelasi antara NT-proBNP dengan severitas dari stenosis mitral serta korelasinya dengan kelas fungsional pasien berdasarkan New York Heart Association (NYHA) (Figure 2.3). ${ }^{24,25}$ Ranganayakulu, et al. melaporkan bahwa NT-proBNP dapat menggambarkan status hemodinamik pasien stenosis mitral dengan menunjukkan penurunan NT-proBNP pada pasien dengan stenosis mitral setelah tindakan komisurotomi balon perkutan yang berkorelasi dengan penurunan volum

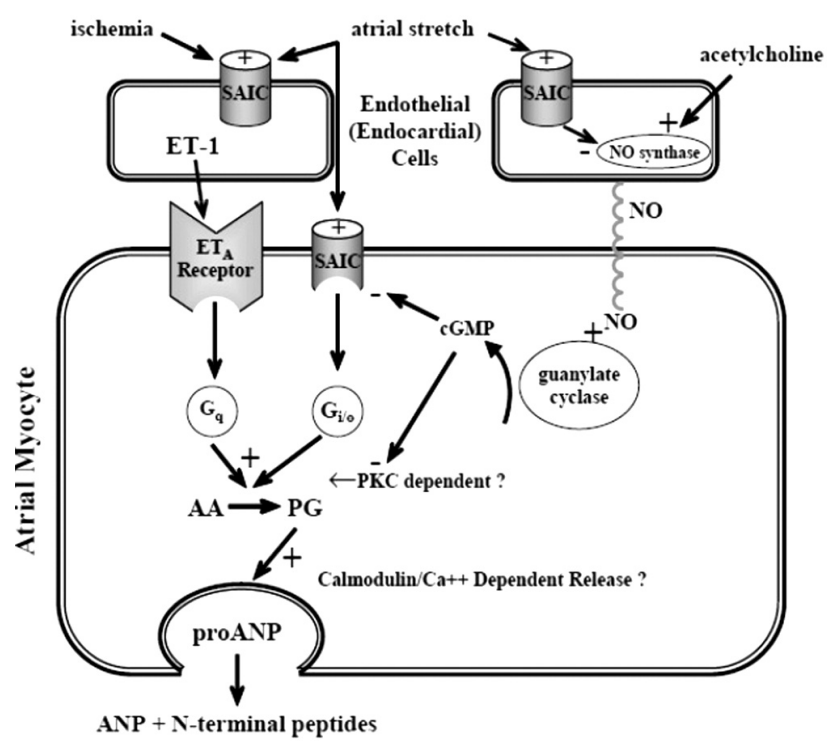

Gambar 1.2 Stimulasi sekresi ANP oleh peregangan miosit atrium $^{19}$

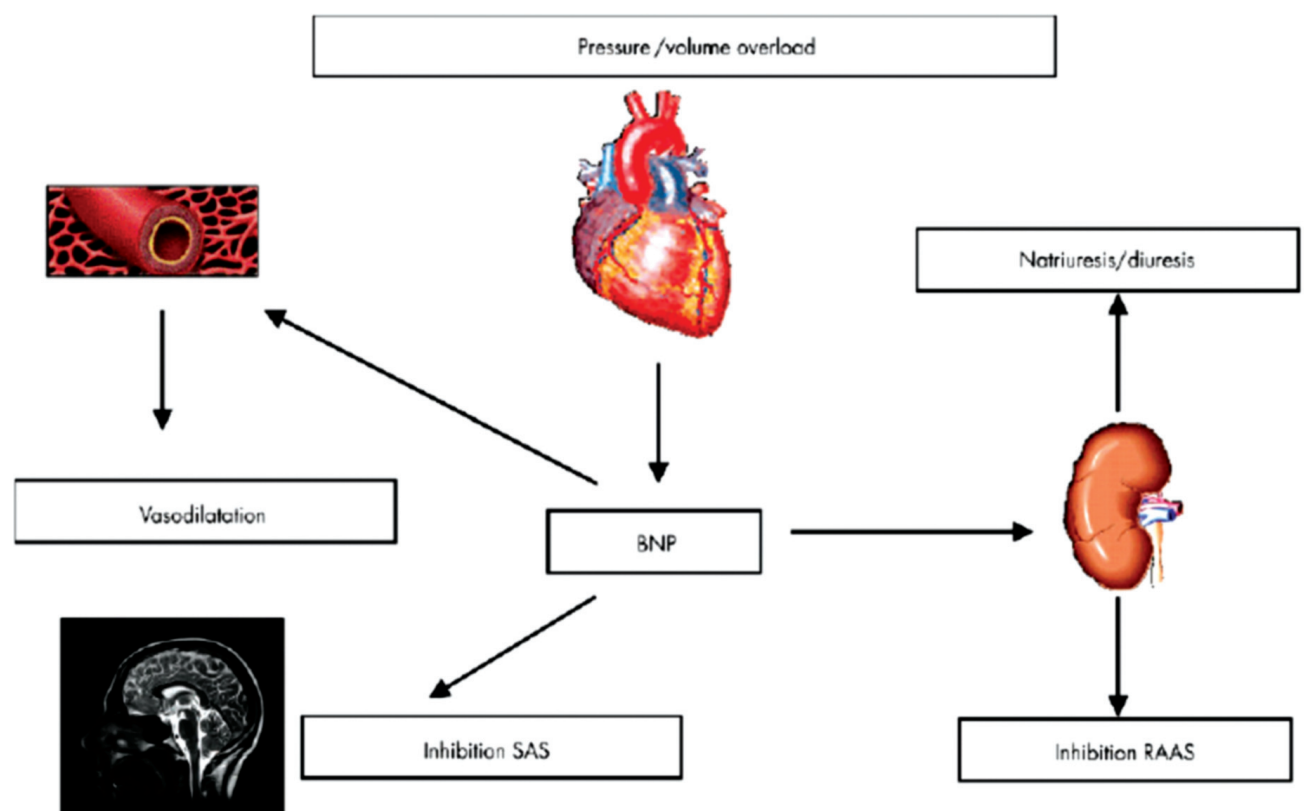

Gambar 1.3. Efek fisiologis BNP dan respon terhadap overload ${ }^{22}$ 
atrium kiri dan tekanan arteri pulmonal. ${ }^{26}$

\section{Mekanisme Remodeling Atrium Kiri}

Remodeling atrium kiri merupakan suatu regulasi adaptif dari miosit kardiak dalam upaya menjaga homeostasis melawan suatu stressor eksternal. ${ }^{27}$ Jenis remodeling bergantung pada ketahanan dan durasi pajanan terhadap stressor. Respon adaptif dapat terjadi pada tingkat ion/gen dalam waktu yang singkat (dalam waktu 30 menit). ${ }^{28}$ Respon adaptif dapat menetap, namun juga dapat reversibel. Pada tingkat seluler, respon adaptif umumnya reversibel dengan mekanisme hibernasi pada pajanan stressor sekitar waktu 1
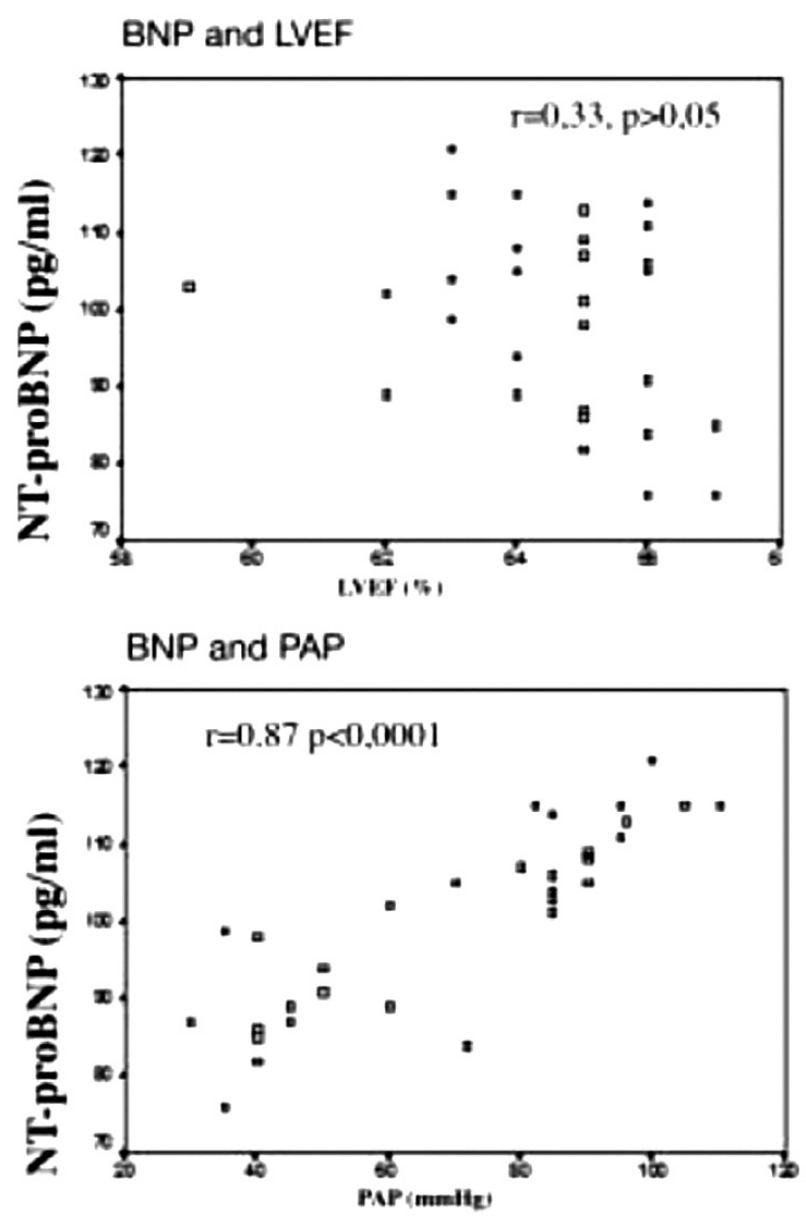

Gambar 1.5. Korelasi NT-proBNP dengan fraksi ejeksi ventrikel kiri dan tekanan arteri pulmonal pada stenosis katup mitral ${ }^{24}$ minggu, namun ketika remodeling terjadi di tingkat matriks ekstraseluler dalam durasi yang lebih lama $(\geq$ 5 minggu); dengan terjadinya apoptosis dan fibrosis, biasanya respon tersebut menjadi ireversibel. ${ }^{29}$

Penyebab "stressor" tersering terhadap miosit atrium adalah takikardia dengan depolarisasi sel yang meningkat serta volum/tekanan overload seperti yang terjadi pada gagal jantung. Stressor spesifik; seperti disfungsi diastolik, iskemia, dan penyakit jantung katup berpengaruh terhadap tekanan dan volum beban terhadap atrium kiri. Serangkaian respon adaptif akan teraktivasi, berikut proses maladaptif. Proses maladaptif meliputi pertumbuhan miosit, hipertrofi, nekrosis, dan apoptosis; perubahan komposisi ekstraseluler matriks; rekalibrasi produksi energi dan ekspenditur; serta perubahan ekspresi kanal ion dan hormon atrium. ${ }^{30}$ Perubahan ini mengaktifkan kaskade reaksi, yang mengarah terhadap remodeling atrium kiri; suatu konsekuensi struktural, fungsional, elektrik, metabolik, dan neurohormonal.

Suatu tanda dari remodeling struktural atrium kiri adalah dilatasi atrium. Perubahan struktural ini akan diikuti dengan perubahan fungsi dari atrium kiri dengan peningkatan fibrosis interstisial yang progresif. Kerusakan fungsi atrial booster pump dan reservoirakan dikompensasi dengan peningkatan fungsi conduit. Atrium kiri merupakan suatu ruangan yang dapat meregang dengan tekanan yang rendah, namun ketika terpajan dengan suatu stressor akut atau kronik, atrium kiri akan meregang dan kaku. Perubahan struktur atrium kiri pada gagal jantung ditandai dengan ekstensif fibrosis interstisial dan hipertrofi miosit. ${ }^{31}$ Selain itu, terdapat juga perubahan degeneratif, seperti edema seluler, nuklear pyknosis, nekrosis dan kematian sel. Kerusakan fungsi atrium kiri ini merupakan hasil perubahan struktural protein dan pergeseran dari fast alpha-myocyte heavy chain menjadi slow beta-myocyte heavy chain isomer. Pergeseran ini merupakan adaptasi overload kronik yang memaksimalkan kerja atrium namun menyebabkan gangguan pada kecepatan kontraksi. Respon adaptif tersebut serupa yang terjadi pada fenotip fetal.Sedangkan pada remodeling atrium kiri yang distimulus oleh takikardia, banyak ditemukan miolisis dan deposisi glikogen.

Perubahan awal pada ultrastruktural seluler dapat terjadi mulai dari 1 minggu dari takikardia atrial terjadi. Mitokondria akan bertambah dalam panjang dan jumlahnya, berbeda dengan jumlah miosit dan jaringan ikat yang pertambahannya tidak signifikan. Berbeda dengan remodeling pada gagal jantung, 
pada remodeling atrium kiri yang dicetuskan oleh takikardia, biasanya tidak ditemukan tanda sel-sel degeneratif, apoptosis, dan fibrosis. Perubahan intra dan ekstraseluler inilah yang berkontribusi dalam terjadinya atrial fibrilasi. ${ }^{32}$

\section{Gangguan Neurohormonal pada Remodeling Atrium Kiri}

Neurohormonal memiliki peran yang sangat penting dalam remodeling atrium kiri; peningkatan ANP, BNP, Angiotensin II,transforming growth factorbeta (TGF- $\beta$ ) dan hiperinervasi simpatis.ANP yang merupakan vasodilator, menurunkan tekanan darah dan menghambat sekresi renin dan endotelin, hipertrofi miosit, dan sintesis fibroblas kolagen. Peregangan atrium kiri merupakan stimulus ANP teraugmentasi oleh endotelin dan dihambat oleh nitrit oksida. ${ }^{32}$ Aktivasi dari sistem simpatis serta angiotensin II akan meningkatkan sekresi ANP dan meningkatkan peregangan atrium dan ventrikel. Kehadiran atrial fibrilasi semakin meningkatkan sekresi ANP. Namun, atrial fibrilasi ataupun kerusakan miokard yang progresif membuat fibrosis miokard sehingga penyimpanan ANP rusak dan mekanisme kompensasi terhambat. ${ }^{33}$

Angiotensin II, aldosteron, dan TGF- $\beta$ berkontribusi pada remodeling melalui proses proliferatif, proinflamatori, fibrotik, dan prothrombotik. Angiotensin II yang teraktivasi oleh renin, yang diproduksi oleh ginjal, mengkonversi angiotensinogen yang diproduksi di liver menjadi angiotensin I. Angiotensin I kemudian dikonversi oleh enzim konversi angiotensin (EKA) menjadi angiotensin II, yang merupakan vasokontriktor poten dan menstimulasi aldosteron. Angiotensin II memiliki efek hipertrofi seluler, apoptosis, fibrosis, infiltrasi neutrophil dan monosit, serta menstimulasi disfungsi endotel dengan menghambat produksi nitrit oksida, meningkatkan vasokontriksi dan reaktivitas platelet. ${ }^{34}$

Angiotensin II merupakan salah satu bagian neurohomonal yang mempunyai peran penting dalam remodeling atrium kiri dengan kemampuannya menginduksi fibrosis interstisial.Angiotensin II berikatan dengan protein $G$ dan mengaktivasi Erk1/Erk2, yang merupakan mitogen-activated protein kinase.Aktivasi dari protein kinase ini menstimulasi transkripsi protein dan mengaktifkan gen spesifik untuk menyandi regulator protein siklus sel yang bertugas dalam pertumbuhan, proliferasi dan diferensiasisel. ${ }^{35}$ Angiotensin II meningkatkan stimulasi TGF- $\beta$, yang berperan dalam stimulasi ekspresi kolagen tipe I dan III yang bertanggung jawab dalam percepatan fibrosis.Sedangkan, aldosteron menginduksi fibrosis melalui fibroblas kardiak dan matrix metalloproteinases (MMPs). ${ }^{36}$

\section{Penyekat EKA}

Peningkatan tekanan di atrium kiri akibat obstruksi katup mitral pada stenosis mitral menyebabkan penurunan pengisian ventrikel kiri dan penurunan curah jantung. Kedua proses ini ditambah dengan peregangan atrium kiri menyebabkan stimulasi pada RAAS yang diawali dengan sekresi renin oleh juxtaglomerular aparatus. Telah dilaporkan pada berbagai studi bahwa stimulasi RAAS memberikan dampak buruk pada miokard yang akhirnya memperburuk klinis pasien. Stimulasi RAAS menyebabkan vasokonstriksi, remodeling kardiak, dan fibrosis. $^{32}$

Pada miokard dengan fungsi yang menurun, level dari $m R N A E K A$,akitivitas dan pengikatan EKAmeningkat.EKAbanyak ditemukan pada dinding arteri dan sel insterstisial jantung. Beban hemodinamik dan tingkat severitas dari beban tersebut berpengaruh pada tingkat ekspresi RAAS. ${ }^{37}$ Penyekat EKA telah dilaporkan memiliki pengaruh menguntungkan pada peregangan atrium, fibrosis interstisial, inflamasi, dan remodeling atrium. ${ }^{32}$

Pada pasien dengan stenosismitral, stimulasi RAAS juga semakin terstimulasi dengan adanya atrial fibrilasi. ${ }^{38}$ Atrial fibrilasi terjadi pada $30-40 \%$ pasien stenosis mitral. Yongjun et al. melaporkan peningkatan level angiotensin II yang lebih meningkat secara signifikan pada atrial fibrilasi dan stenosis mitral dibandingkan pasien atrial fibrilasi pada regurgitasimitral. ${ }^{38}$ Penyekat EKA memiliki dampak yang baik pada atrial fibrilasi dengan mencegah stimulus takikardia dan remodeling struktural serta proses fibrosis. ${ }^{11}$ Chockalingam et al. pada Symptomatic Cardiac Obstruction-Pilot Study of Enalapril in Mitral Stenosis (SCOPE-MS)melaporkan keuntungan pemberian enalapril pada pasien stenosis mitral, didapatkan peningkatan kapasitas fungsional pada pasien yang diberikan enalapril selama 4 minggu, tanpa menunda waktu operasi. ${ }^{13}$ Pada umumnya, obstruksi katup jantung kiri dihindari untuk diberikan vasodilator termasuk penyekat EKA.Namun, saat ini 
beberapa studi dan panduan klinik sudah memasukkan penyekat EKAsebagai terapi pada stenosis katup aorta dengan terutama dengan koeksistensi hipertensi ataupun fraksi ejeksi rendah. ${ }^{39}$ Chockalingam et al. padaSymptomatic Cardiac Obstruction-Pilot Study of Enalapril in Aortic Stenosis (SCOPE-AS) melaporkan keamanan dan peningkatan kapasitas fungsional pada pasien dengan stenosis katup aorta setelah diberikan enalapril selama 4 minggu. ${ }^{40}$

\section{Rangkuman}

Gejala dari stenosis mitral berkaitan erat dengan konsekuensi hemodinamik yang diakibatkan oleh obstruksi dari katup mitral. Peregangan atrium kiri dan penurunan curah jantung mengaktifkan serangkaian dari aktivasi neurohormonal. Aktivasi neurohormonal ini merupakan respon adaptif. Namun, aktivasi neurohormonal yang progresif memiliki efek merugikan yang menyebabkan suatu remodeling. Remodeling atrium kiri memperburuk hemodinamik pada stenosis mitral.Remodeling ini diperantai oleh aktivasi RAAS dan simpatis yang memperburuk gejala dari pasien dengan stenosis mitral.Blokade dari aktivasi RAAS dan simpatis dapat memperbaiki gejala pada pasien dengan stenosis mitral dengan melakukan observasi pada status hipotensi.

\section{Daftar Pustaka}

1. Iung B, Baron G, Tornos P, Gohlke-Barwolf C, Butchart EG, et al. Valvular heart disease in the community: a European experience. Current problems in cardiology 2007;32:609-61.

2. Data Stenosis Mitral 2010-2014. Unit Rekam Medis Rumah Sakit Jantung dan Pembuluh Darah Harapan Kita; 2015.

3. Nishimura RA, Otto CM, Bonow RO, Carabello BA, Erwin JP, 3rd, et al. 2014 AHA/ACC guideline for the management of patients with valvular heart disease: executive summary: a report of the American College of Cardiology/American Heart Association Task Force on Practice Guidelines. J Am Coll Cardiol 2014;63:2438-88.

4. Carapetis JR, Steer AC, Mulholland EK, Weber M. The global burden of group A streptococcal diseases. The Lancet Infectious diseases 2005;5:685-94.

5. Carabello BA. Indications for mitral valve surgery. J Cardiovasc Surg (Torino) 2004;45:407-18.

6. Carabello BA. Is it ever too late to operate on the patient with valvular heart disease? J Am Coll Cardiol 2004;44:376-83.
7. Otto CM, Bonow RO. Rheumatic Miral Valve Disease. Valvular heart disease : a companion to Braunwald's heart disease. 3rd ed. Philadelphia: Saunders Elsevier; 2004:221-42.

8. Abhayaratna WP, Seward JB, Appleton CP, Douglas PS, Oh $\mathrm{JK}$, et al. Left atrial size: physiologic determinants and clinical applications. J Am Coll Cardiol 2006;47:2357-63.

9. Kennedy JW, Yarnall SR, Murray JA, Figley MM. Quantitative angiocardiography. IV. Relationships of left atrial and ventricular pressure and volume in mitral valve disease. Circulation 1970;41:817-24.

10. Rahimtoola SH, Durairaj A, Mehra A, Nuno I. Current evaluation and management of patients with mitral stenosis. Circulation 2002;106:1183-8.

11. Novo G, Guttilla D, Fazio G, Cooper D, Novo S. The role of the renin-angiotensin system in atrial fibrillation and the therapeutic effects of ACE-Is and ARBS. Br J Clin Pharmacol 2008;66:345-51.

12. Ehrlich JR, Hohnloser SH, Nattel S. Role of angiotensin system and effects of its inhibition in atrial fibrillation: clinical and experimental evidence. Eur Heart J 2006;27:512-8.

13. Chockalingam A, Venkatesan S, Dorairajan S, Chockalingam V, Subramaniam T, et al. Safety and efficacy of enalapril in multivalvular heart disease with significant mitral stenosis-SCOPE-MS. Angiology 2005;56:151-8.

14. Baumgartner H, Hung J, Bermejo J, Chambers JB, Evangelista A, et al. Echocardiographic assessment of valve stenosis: EAE/ ASE recommendations for clinical practice. European journal of echocardiography : the journal of the Working Group on Echocardiography of the European Society of Cardiology 2009; 10:1-25.

15. Carabello BA. Modern management of mitral stenosis. Circulation 2005;112:432-7.

16. Gash AK, Carabello BA, Cepin D, Spann JF. Left ventricular ejection performance and systolic muscle function in patients with mitral stenosis. Circulation 1983;67:148-54.

17. Hoit BD. Left atrial size and function: role in prognosis. J Am Coll Cardiol 2014;63:493-505.

18. Rodriguez L, Gillinov A. Mitral Valve Disease. In: Topol EJ, ed. Textbook of Cardiovascular Medicine. 3rd ed: Lippincot Williams\&Wilkins; 2007:347-65.

19. Dietz JR. Mechanisms of atrial natriuretic peptide secretion from the atrium. Cardiovascular research 2005;68:8-17.

20. Hayashi Y, Ohtani M, Sawa Y, Hiraishi T, Kobayashi Y, et al. Left atrial diameter is a simple indicator of a deficiency in atrial natriuretic peptide secretion in patients with mitral stenosis: efficacy of postoperative supplementation with synthetic human alpha-atrial natriuretic peptide. J Cardiovasc Pharmacol 2004;44:709-17.

21. Maeda K, Tsutamoto T, Wada A, Hisanaga T, Nishimura T, et al. Low dose synthetic human atrial natriuretic peptide infusion in a 


\section{Jurnal Kardiologi Indonesia}

patient with mitral stenosis and severe pulmonary hypertension. Jpn Circ J 1999;63:816-8.

22. Weber M, Hamm C. Role of B-type natriuretic peptide (BNP) and NT-proBNP in clinical routine. Heart 2006;92:843-9.

23. Haug C, Metzele A, Kochs M, Hombach V, Grunert A. Plasma brain natriuretic peptide and atrial natriuretic peptide concentrations correlate with left ventricular end-diastolic pressure. Clin Cardiol 1993;16:553-7.

24. Iltumur K, Karabulut A, Yokus B, Yavuzkir M, Taskesen T, et al. N-terminal proBNP plasma levels correlate with severity of mitral stenosis. J Heart Valve Dis 2005;14:735-41.

25. Selcuk MT, Selcuk H, Maden O, Erbay AR, Temizhan A, et al. The effect of percutaneous balloon mitral valvuloplasty on $\mathrm{N}$-terminal- pro B- type natriuretic peptide plasma levels in mitral stenosis. Int Heart J 2007;48:579-90.

26. Ranganayakulu KP RD, Vanajakshamma V, Santosh kumar C, Vasudeva Chetty P. N-Terminal-proBNP, a surrogate biomarker of combined clinical and hemodynamic outcomes following PTMC. Journal of the Saudi Heart Association2015.

27. Nattel S. Electrophysiologic remodeling: are ion channels static players or dynamic movers? J Cardiovasc Electrophysiol 1999;10:1553-6.

28. Goette A, Honeycutt C, Langberg JJ. Electrical remodeling in atrial fibrillation. Time course and mechanisms. Circulation 1996;94:2968-74.

29. Li D, Fareh S, Leung TK, Nattel S. Promotion of atrial fibrillation by heart failure in dogs: atrial remodeling of a different sort. Circulation 1999;100:87-95.

30. Colucci WS BE. Pathophysiology of Heart Failure. In: Zipes D LP, Bowon RO, Braunwald E, ed. Braunwald's Heart Disease: A Textbook of Cardiovascular Medicine 7th ed: Philadephia, PA: W.B. Saunders; 2005:305-38.

31. Khan A, Moe GW, Nili N, Rezaei E, Eskandarian M, et al. The cardiac atria are chambers of active remodeling and dynamic collagen turnover during evolving heart failure. J Am Coll Cardiol 2004;43:68-76.

32. Casaclang-Verzosa G, Gersh BJ, Tsang TS. Structural and func- tional remodeling of the left atrium: clinical and therapeutic implications for atrial fibrillation. J Am Coll Cardiol 2008;51:111.

33. Khan R, Sheppard R. Fibrosis in heart disease: understanding the role of transforming growth factor-beta in cardiomyopathy, valvular disease and arrhythmia. Immunology 2006;118:1024.

34. Brown NJ, Vaughan DE. Prothrombotic effects of angiotensin. Advances in internal medicine 2000;45:419-29.

35. Goette A, Staack T, Rocken C, Arndt M, Geller JC, et al. Increased expression of extracellular signal-regulated kinase and angiotensin-converting enzyme in human atria during atrial fibrillation. J Am Coll Cardiol 2000;35:1669-77.

36. Rude MK, Duhaney TA, Kuster GM, Judge S, Heo J, et al. Aldosterone stimulates matrix metalloproteinases and reactive oxygen species in adult rat ventricular cardiomyocytes. Hypertension 2005;46:555-61.

37. Unger T, Li J. The role of the renin-angiotensin-aldosterone system in heart failure. J Renin Angiotensin Aldosterone Syst 2004;5 Suppl 1:S7-10.

38. Yongjun Q, Huanzhang S, Wenxia Z, Hong T, Xijun X. Histopathological characteristics and oxidative injury secondary to atrial fibrillation in the left atrial appendages of patients with different forms of mitral valve disease. Cardiovascular pathology : the official journal of the Society for Cardiovascular Pathology 2013;22:211-8.

39. Vahanian A, Alfieri O, Andreotti F, Antunes MJ, Baron-Esquivias $\mathrm{G}$, et al. Guidelines on the management of valvular heart disease (version 2012): the Joint Task Force on the Management of Valvular Heart Disease of the European Society of Cardiology (ESC) and the European Association for Cardio-Thoracic Surgery (EACTS). Eur J Cardiothorac Surg 2012;42:S1-44.

40. Chockalingam A, Venkatesan S, Subramaniam T, Jagannathan V, Elangovan S, et al. Safety and efficacy of angiotensin-converting enzyme inhibitors in symptomatic severe aortic stenosis: Symptomatic Cardiac Obstruction-Pilot Study of Enalapril in Aortic Stenosis (SCOPE-AS). Am Heart J 2004;147:E19. 